\title{
Globalization's Problematic for Labour: Three Paradigms
}

\author{
Paul Bowles \\ University of Northern British Columbia
}

\begin{abstract}
Globalization's impact on workers worldwide is contested. The nature of labour's responses is similarly contested. To a significant degree this contestation arises because of different conceptualizations of 'globalization'. I distinguish between three paradigms of globalization: neoclassical liberalism, anti-neoliberal globalism and multi-centred statism. I analyze each paradigm in terms of their identification of globalization's problematic for labour and the responses from labour that they suggest. The positions of China and India in these problematics and responses are discussed.
\end{abstract}

KEYWORDS

globalization, international labour standards, labour, neoliberalism

\section{Introduction}

Workers in all parts of the world have seen their working conditions and rewards affected by the forces of globalization. These changes have been complex, often ambiguous and have had differential impacts leading to new inter- and intra-class frictions and fissures. A coherent response from labour has, not surprisingly, been difficult to formulate either locally, nationally or internationally. Yet the task remains pressing. As the global recession's impacts are felt by workers across the globe, solidaristic responses to globalization's dynamics are more important than ever.

The re-emergence of China and India as global economic powers has added further dimensions. Analyzing the impacts of globalization on the vast labour forces of these two countries is itself a large undertaking; six of the papers in this volume are focused on this question. They remind us of the differentiated nature of the working class, the difficulties, possibilities and limits of organized responses in these two countries and the complexities of the interactions between globalization, state and labour.

Many of the impacts which they discuss have specific roots in the Indian and the Chinese economic, social and political systems. Included here are the continued informalization of work in India and the expansion of the informal sector despite exposure to the 'modernizing' forces of globalization (Harriss-White, this volume). The agricultural crisis in rural India and its historic links to 'landlordism' (Ramachandran and Rawal, this volume) present a picture of India far removed from that usually portrayed by the western media and Indian politicians alike. For the latter, the emphasis is more likely to be on the promise of India's burgeoning IT sector but the new 'flexi workers' in these firms are facing their own 
forms of insecurity. In China, the particular role of migrant workers in China's exportoriented sector, constrained by residency categories and shaped by gender relations, demonstrate how the 'Chinese model' has affected many of its workers (Chan et al, this volume) in an environment where labour has been effectively controlled by the state (Blecher, this volume).

Notwithstanding these specificities, the experience of labour in these two countries of the South also bears some comparison with the generic changes which have affected workers worldwide as a result of contemporary global capitalism's dynamics. In the advanced industrial countries of the North, there have also been trends towards the informalization of work, often termed casualisation, with the growth of largely non-unionized service sector jobs organized in 'flexible' labour regimes. The emergence of so-called 'Third World' sweatshop working conditions, gendered and racialized, in the core countries has been shocking but perhaps not surprising. To these similarities, we can also add factors specific to labour in the advanced industrialized countries. The holes in social safety nets have become larger and more have slipped through as many states have sought to reduce expenditures and add further disciplines to the labour force. Trade union and employment rights have been scaled back in many countries and real wages have stagnated with income growth coming largely through more hours being worked and higher labour force participation rates. Labour market flexibility, enshrined in OECD policy reports, and welfare state retrenchment have been the dominant policies across the industrialized world for the past two decades. This aspect of neoliberalism remains largely unchallenged despite its spectacular failures in other areas such as the under-regulation of financial institutions and markets.

Labour in both the advanced industrial core and in the developing world has therefore been challenged by many factors in the period marked by contemporary globalization. For the working classes of India and China, their integration into global capitalism has been complex and as other papers in this volume document, their responses have been primarily local. Labour in the advanced industrial countries have also engaged in local and national responses; but, as well, organized labour particularly from North America and the European Union have been vocal in pursuing redress at the international level. It is labour in these countries, often in conjunction with sections of capital, that have lobbied their states for international labour standards. As Singh and Zammit (2004: 85-86) have written 'for the last 20 years the United States and a group of advanced countries, US trade unions, and the International Confederation of Free Trade Unions (ICFTU) have led a concerted campaign at the General Agreement on Tariffs and Trade (GATT) and subsequently at the World Trade Organization (WTO) for instituting higher labour standards in developing countries. Developing countries, have however, resolutely opposed any discussion of labour standards at the WTO, regarding these as thinly veiled protectionist devices.' (See Hensman, this volume, for details of labour's opposition to a so-called 'social clause' in India).

And yet while these debates have occurred at the international level, others have argued that labour's response should be primarily national in focus. This is pointedly the case for Gindin (2004: 6) who argues that 'the greatest international contribution the American 
left can make involves coming to grips with their own state.' The appropriate level(s) for progressive responses to globalization remain enduring problems (see Flynn and O’Brien, this volume, for further discussion).

But questions of strategy and response depend on the problematic being addressed. And here, we are in need of greater conceptual clarity so that the widely-cited but too often ill-specified 'forces of globalization' are subject to greater scrutiny. If we are to find solidaristic labour responses to globalization in countries as diverse as China and India and the advanced industrial countries, then globalization's problematic for labour needs careful analysis. The possibilities for local and national labour struggles and their potential contributions to internationalist solutions, depends on the precise specification of the problematic to be addressed. That is, how the various levels of response and resistance are linked depends on how 'globalization' is analyzed.

The purpose of this paper is to provide a contribution to this analysis. Many interpretations of the concept of globalization have been formulated with very different implications for labour. While some authors choose to ignore this fundamental point and proceed as if the meaning of globalization was self-evident and non-contentious, an essential first step must be an interrogation of the term globalization itself, an examination of some of the main ways in which it has been conceptualized, as a prelude to a detailed analysis of its workings. For this reason, the purpose of this paper is to identify three leading paradigms of globalization and set out what each implies about globalization's 'problematic' for labour. I also explore the policy responses that each paradigm suggests.

\section{Mapping the Dynamics of Globalization: Three Paradigms and Their Implications for Labour}

There is no agreement on the meaning of 'globalization'. Instead of proposing a generic interpretation, I distinguish here between three different paradigms and present their interpretations of the dynamics of globalization highlighting what they identify as globalization's problematic for labour. As I will show, specifying the problematic that must be addressed depends crucially on how the dynamics of globalization are conceptualized.

The three paradigms I identify are, firstly, the neoclassical liberal paradigm. Based on trade theory developed by economists over the past two hundred years, this paradigm views a liberal global trading order as the main manifestation of globalization and as beneficial to the majority; the policy issue becomes how to prevent the minority obstructing globalization's march and how to minimize the adverse effects on them. The second paradigm I term antineoliberal globalism. This paradigm starts from the proposition that globalization is better viewed as an ideology, an 'ism', that of globalism. Moreover, the dominant form of this ideology over the past two decades has been that of neoliberal globalism. The problematic that this presents for labour stems from the (deliberate) shift of power to capital and away from labour and the state. The response varies from arguments in favour of a social democratic form of globalism ('counter-hegemonic globalization' for Evans, 2008), to support for de-globalization. The third paradigm, that of multi-centred statism, argues that 
globalization is a process that has a number of sources and is driven by a number of states, including non-Western ones. Here the problematic concerns the space available to these states and how their internal socio-economic dynamics might work to ensure that labour receives a fair share of the gains. Each of these three paradigms is analyzed in more detail below. ${ }^{1}$

\section{NEOCLASSICAL LIBERALISM}

Neoclassical economics typically privileges trade liberalization and trade flows as evidence of global integration. In general, financial liberalization is also seen as beneficial but, even before the current crisis, this tenet was more controversial than trade liberalization even among neoclassical economists, with some recognizing the destabilizing and welfare-reducing costs of financial liberalization. ${ }^{2}$ As a whole, neoclassical economics has been more comfortable dealing with the case for trade liberalization. Starting from Ricardian trade theory, the argument runs that globalization increases global welfare by reaping the benefits of greater specialization. As Deepak Lal puts it if the newly reconstructed [liberal international economic order] can be maintained, it offers the prospect (as did the first to the Victorians) of a sustained period of universal prosperity' (1999: 212). However, while global welfare may increase it is not necessarily the case that all participants in the globalizing and liberalizing economy will benefit. 'Universal prosperity', notwithstanding, as Lal recognizes 'for developed countries the major threat perceived from globalization is to the living standards of their poorest and least-skilled workers from trade with the Third World' (1999: 216).

Given the perceived threat to labour in the North from increased trade with the countries of the South, it is not surprising to find that much of the economics literature has been concerned with finding and measuring the extent of globalization's impact on the wages of workers in industrialized countries (see, for example, Leamer 1998; Feenstra 1998; Jones 2000). ${ }^{3}$

Widening income inequality in the core countries has been attributed at least in part to the decline in the incomes of unskilled workers whose jobs have disappeared, been offshored, or whose wages have declined as a result of competition from the unskilled labour from developing countries embodied in their exports to the industrialized countries. Globalization skeptics have argued that such wage trends have very little to do with globalization per se and are the result of domestic political decisions to adopt neoliberal policies (see, for example, Hay 2006). There is a debate, therefore, on the extent to which globalization is the cause of the deteriorating labour market conditions and outcomes experienced by workers in industrialized countries. To those for whom globalization is a major causal force, labour in industrialized countries competes directly with labour from developing countries.

Globalization, on this reading, is likely to lead to protectionist sentiment among workers in industrial countries, pitted as they are against lower cost labour imports from developing countries. It should be remembered that in the last phase of globalization, in the late nineteenth century, migrant receiving countries including the U.S. imposed significant 
restrictions on immigration in response to the political pressures from domestic labour organizations fearing the competition from new migrants. Neoclassical economists do not suggest protectionist remedies however. Typically, the blame is laid on the low human capital of the industrial country workers with protectionism only benefiting them at the expense of greater global welfare. The solution, therefore, is for the adjustment costs to be minimized, perhaps by temporary protection from import surges, but more importantly by longer term retraining programs which shift workers in industrial countries out of those industries in which developing countries have a comparative advantage.

The natural unfolding of the market, therefore, results in some workers in industrialized countries being pitted against their developing country counterparts. The losses felt by the former are more than offset by the gains made by the latter. That is, neoclassical economics has the interesting but troublesome prediction that globalization as trade liberalization is a positive sum game but it nevertheless necessarily involves losses for workers in some countries. Most of the academic and policy attention has been focused on how to ease the transition costs for these workers.

Empirical studies initially focused on particular industries with high import content, especially footwear and textiles (although in theory the depressing wage effect should be felt by all in the tradable goods sector). But the rise of China and India has subjected much broader segments of the industrialized countries' working class to the threat of competition from labour abroad. Now everyone from computer programmers and software engineers to workers in the highly capital intensive auto sector are threatened with job loss and lower wages. The response has been for industrialized countries' governments to place even greater stress on the importance of education for the knowledge based economy; with those who fail to accept the challenge facing a low wage future. The 'globalization problematic', as far as labour is concerned, concerns relatively highly paid, typically unionized, relatively low skilled workers in core countries. Workers in developing countries are generally presumed to be the beneficiaries of globalization.

Within this framework, international labour standards may also play an important policy role. Such standards are likely to be advocated by unions in industrial countries so that trade - and competition with developing country workers - is conducted on a 'level playing field'. That is, industrialized country workers are likely to argue that the 'endowments' which countries bring with them to the trade table should not include 'unfair' labour standards, an argument which they have been successful in translating into state policy in many countries as noted above. ${ }^{4}$

The basic arguments of the neoclassical interpretation, that workers are competing with each other across countries and that the best way for industrial country workers to respond is to increase their human capital, has become standard fare in policy making circles. Whether the driving force behind globalization is the technology which allows communication and coordination to take place globally and/or the rational wisdom of trade negotiators in liberalizing trade (and investment) rules, the result is a redistribution of income from the trade-exposed part of labour's aristocracy in the core to labour in the developing country export sectors. 'Transition' and 'retraining' strategies are the policy 
response. ${ }^{5}$ The possibilities for common responses by labour are limited to impossible as labour is conceived in national terms (as are capital, and the underlying explanandum, relative capital/labour ratios).

One way out of this conflict recently highlighted by Rodrik (2008) occurs if competition from imports spurs productivity growth in the import competing sector in core countries, a possibility ignored in static trade theory. If this is the case, then wages need not fall if workers in the core retain some of the ensuing productivity gains (although whether this happy outcome arises through agency or the market is unclear) and the problem shrinks to being one of adjustment for displaced workers. Indeed, other workers in developed countries may gain from China's export of cheap consumer goods; in many cases, workers in the core are not threatened by China's low wages but benefit from them. This, of course, raises a whole set of new concerns.

\section{ANTI-NEOLIBERAL GLOBALISM}

This paradigm starts from the proposition that globalization represents a global shift in power towards capital and away from labour. Globalization has effectively empowered multinational corporations in their relations with nation states and labour so that they are able to play off states and workers against each other in their global search for profits. Associated with the neoliberal revolution of the 1980s, globalization is viewed as a response to the profits crisis and capital-labour impasse of the 1970s (Harvey 2005). The deliberate policies enacted to unleash market liberalization, or market fundamentalism, through the auspices of the international financial institutions freed capital from its national fetters and created the conditions for global capital accumulation directed by the emerging 'transnational capitalist class' (Sklair 2001). Labour, in all countries, has been weakened as a result, its bargaining power reduced by mobile transnational capital and compliant national elites.

While weakening labour everywhere, the globalization problematic is likely to be felt most intensely where labour rights are weakest. In China, for example, Anita Chan (2001) describes China's workers as being metaphorically, and often literally, 'under assault' from the forces and agents of globalization; while in India enterprise surveys show 'an aggressive shift in employment from permanent to temporary, casual and contract employment [with] a systematic transfer of jobs from the bargainable or unionized category' (Sharma 2006: 2083). Globalization skeptics would point out, though, that the informalization of labour in India precedes globalization and that the Supreme Court has sometimes ruled against labour rights. In core countries, where previous expansions of the market led to extensive and successful Polanyian reactions with the establishment and expansion of national welfare states, there are still important challenges - but the rawness of global capitalism's new found power is most often found in the periphery where such a counter movement against the attempt to establish the 'self-regulating market' is still only weakly developed.

Transnational capital does have pressure points, however, on which action is possible. One such pressure point is through consumers and NGOs. With the state (intentionally) weakened by neoliberalism, the governance of the corporation becomes a matter of direct 
public interest. Thus, NGOs such as the Clean Clothes campaign, publicly challenge corporations to ensure that working conditions in their global supply chains meet some minimum standards. Corporate codes of conduct, voluntarily developed by private agents, become a key regulator to raise working conditions at the most exploitative links of the supply chain by setting minimum standards. Private sector agencies become the monitors and enforcers of these standards through site visits, and working conditions in the global economy may gradually become governed perhaps by a combination of private actors and governments.

Gay Seidman's study of three successful consumer-driven campaigns ${ }^{6}$ shows that all three involved government threats of trade sanctions against companies with poor labour records. Her conclusion is that 'transnational consumer movements can increase the bargaining power of the global workforce ... but they cannot replace national governments' (2007). Seidman also comments that there are intractable difficulties in independent workplace monitoring. There are many reasons to doubt the efficacy of private governance structures, not the least of which is the fear is that it is perhaps only the first links in the chain that are monitored, and that poor working conditions are shifted to the links lower down the chain, and further removed from the consumer, which are more difficult to monitor effectively.

International labour standards may again play a role, not as a defensive action by globally privileged sections of the working class as suggested under neoclassical liberalism, but as a collective defence by workers against the enhanced powers of capital. International labour standards, in this framing, can be part of a response aimed at reclaiming for labour some of the rights and bargaining power that it has lost under the neoliberal onslaught. This type of approach, often championed by the ILO through its 'decent work' agenda, could contribute to raising global labour standards; such a strategy might be widely supported since labour solidarity is more readily achievable if globalization is interpreted in its neoliberal form. There is the possibility that the expansion of transnational corporations gives workers across different countries shared objectives, and of the consequent development of 'global unions' and of global bargaining (Lerner 2007); it has been shown by Kay (2005) that NAFTA had the unanticipated effect of creating a new opportunity structure for labour, stimulating cooperation among North American unions. The objection to this is that the focus of labour standards on formal sector work (and unions) runs the risk of pushing work back into the informal sector, a move which would be socially regressive and counterproductive (Kabeer 2004).

Campaigns over labour standards and moves to establish global unions and global bargaining broadly describe attempts at constructing a 'fair globalization', to use the preferred term of the World Commission on the Social Dimensions of Globalization, through strengthening the power of global labour in its dealings with global capital and opening up a space for global social democracy. This response accepts globalization as a technologically-driven reality, but seeks to change its neoliberal governance to a more benign, labour-friendly, form. As the World Commission, which included such antineoliberal globalism luminaries as Joseph Stiglitz, writes 'we judge that the problems we have 
identified are not due to globalization as such but as deficiencies in its governance. Global markets have grown rapidly without the parallel development of economic and social institutions necessary for their smooth and equitable functioning. At the same time, there is concern about the unfairness of key global rules on trade and finance and their asymmetric effects on rich and poor countries' (2004: xi). Here, the 'unfairness' are the trade rules used by advanced countries.

Other responses, such as the Asian Minimum Wage campaign, organized by the Committee for Asian Women, also seek to pressure governments to ensure that globalization is more equitable. By targeting nine countries in the region, the campaign seeks to build solidarity between workers across national borders and to ensure that no one country's workers will lose from adopting wage raising measures.

Another set of arguments, on comparable lines, but casting challenges and opportunities differently, proposes the possibility of 'counter-hegemonic globalization' (Evans 2008). This requires a 'movement of movements' that brings together diverse constituencies, of which labour is only one - others include the wider range of economic and social rights, women and the environment - as well as operating transnationally and integrating different levels and scales of action. This might be seen as a transnational development of social movement unionism.

There are other responses on offer too. For example, Walden Bello (2002) has promoted the idea of 'de-globalization' a strategy which places much greater weight on the nation state as a site of democracy, control and regulation of social outcomes. The approach is again based on the assumption that neoliberal globalism is a political project and, as such, is politically reversible. The push for liberalization under the WTO can be halted and the neoliberal agendas of the World Bank and IMF reversed. In their place will be the return of an international, not global, economy in which nation states serve as the basic units of analysis. ${ }^{7}$ It is within these political spaces that each society can forge its own path and solve its own distributional conflicts; states are linked together through trade and investment but no longer harmonized along neoliberal lines. In this response, therefore, it is both neoliberalism and globalism that need to be opposed. But in so far as the argument seems to suggest 'bringing back the nationalist developmental state' it may be reckoned problematic. Is it likely that 'national bourgeoisies' and their political representatives will reform neoliberal globalization (Evans 2008)?

Still, many accounts of 'neoliberal globalization' place the action at the global level, with global capital confronting global civil society and/or global labour, and Bello does a great service by re-emphasizing the importance of the nation state. Analyses focusing on the global level run the risk of missing the important global-nation state-local complexities that determine how globalization processes play out in practice. In this context, states have been variously described as 'competition', 'adaptive' and 'transmitting' as ways of capturing the limited role that the state plays under global neoliberalism (see, for example, Cerny 2000). But this narrative too misses the myriad ways in which governments at various levels seek to influence globalization's specific impacts, sometimes promoting and sometimes constraining interactions with foreign capital and markets. In the Chinese case, the local state has been a 
key player in shaping the interactions with global capital, often as 'compradors' with foreign capital to the detriment of workers. In India, too, different states have pursued different strategies, and though most are now seeking to persuade capitalists, both local and international, that they provide an attractive 'investment climate', they differ widely in terms of the social protection that they offer. All of this points to the need for a including more detailed examinations of the state, at its various levels, in determining globalization's impacts. The global financial crisis has also led to a major rethinking of the role of the state in regulating national and global political economies as neoliberalism's dominance fades. It is not so much the state that is withering away as neoliberalism's appeal.

\section{MULTI-CENTRED STATISM}

The necessity of examining the state is central to analyses of globalization which suggest that the neoliberal phase has run its course and that a new dynamic is emerging. Of course, states have always been central to accounts of globalization which equate it with imperialism. Here, the U.S. and, to a lesser extent, European countries are seen as adopting globalization as a project, backed by state power, to open up foreign markets for 'their' firms. (See Petras and Veltmeyer 2001; Harvey 2003 for example). But these accounts are all premised on the assumption that globalization - aka imperialism - is a western-centric process. The source of globalization lies in the centres of global political power, most prominently Washington DC, its resistance most obviously located in the anti-imperialist struggles and rhetoric of Chavez and Morales. The places of China and India are underexplored in these accounts; they are typically viewed as being incorporated tout court into global capitalism's expansion. Implicitly it is typically western capital and western interests that drive global integration with western state policy geared to promoting this.

But this account misses the possibility that globalization might be a multi-centred process. It is in this possibility that the importance of China and India are particularly evident, not simply as repositories of western capital and outsourcing but as potentially important emerging centres of global power, both economic and political. This requires a rethinking of the dynamics of globalization. Instead of equating globalization with Americanization, and with US imperial power, the concept needs to be refined to allow multiple centres and dimensions. Befu (2007) has made the case with respect to Japan. He argues that "the concept of "Japanization" parallels such concepts as "Westernization" and "Americanization", which have sometimes been equated with globalization. "Japanization" has as much utility for the understanding of globalization.' (2007: 151). He supports his argument that 'there is no intrinsic reason why 'universal theory' or concepts applicable globally must be born out of the Western experience' (ibid) by examining the influence of Japan on global culture; he might just as easily have looked at Japanese influence on management practices.

Certainly the evidence of the rise of multinationals from the South (Goldstein 2007) suggests that western capital is not unchallenged in the global market. Multinationals from China and India have been prominent among them and many Chinese firms, typically stateowned, have 'gone global' as part of their growth strategy and have been actively supported 
by the government in this process. In this regard, China is unique in that, as Williamson and Zeng (2007) note, China's own global firms have emerged at a much earlier stage of capitalist development than they did elsewhere. Both China and India are now significant sources of foreign direct investment in some sectors with, for example, the Indian group Tata having acquired Corus, the last surviving at least partially British steelmaker, and more recently such iconic former British companies as Jaguar and Land Rover, and China's Lenovo acquiring IBM Thinkpad. Politically, too, China has 'gone global' where 'the early years of the twenty-first century have witnessed a growing awareness on the part of the CCP's theorists and leaders that globalization offers China an opportunity to project its influence and power beyond the boundaries of the Chinese nation-state, and that China could operate throughout the world in a far more proactive and energetic manner than had hitherto been the case.' (Knight 2008: 171)

But this strategy of 'going global' is premised on a particular interpretation of globalization. Of course, the term globalization has been debated in China as elsewhere (see Knight 2008) with a spectrum of views evident; the dominant view, however, is that globalization should be seen as an objective, technologically driven process and, as such, capable of being used by a variety of social systems. That is, it (allegedly) transcends debates over capitalism and socialism and can be fashioned to be consistent with either. As Yu (2007: 59) has noted, in the discussion of globalization ... Chinese intellectuals, for the most part, no longer regard it as a synonym for capitalism, although they know clearly that the developed capitalistic countries control the progress of globalization.' This opens the possibility that 'unlike some Western political leaders who downplay state sovereignty in the global age, Chinese leaders make sovereignty the basis on which all political and economic activities take place, including economic globalization' (ibid: 57). As a result, China's leaders have sought integration into the global economy but on the basis of retaining state sovereignty, a path which has included the training of high-level state cadres to 'become the pivotal force of the Chinese government in dealing with the process of globalization' (ibid: 55).

The central point of this 'globalization with Chinese characteristics' is that it is consistent with national sovereignty and the pursuit of a national developmentalist agenda. Such an agenda requires that globalization be governed in such a way as to allow development space. If the term the 'Beijing Consensus' (Ramos, 2004) means anything it means this (see also Dirlik 2007). In this respect, this paradigm bears similarities with the 'deglobalization' route outlined above. But there are some differences. The multi-centred statist approach places much greater emphasis on the state - and multiple states - as the drivers and continued occupants of the driving seat of globalization. The frictions in the global political economy are between globalizing states (and their firms) rather than between global capital and global civil society with states relegated to the back seat. Rather, the emerging powers of China and India are growing in their influence of global governance. As the Doha round collapsed in the summer of 2008, it was significant that it was not the result of the usual US versus European disagreements but because developing countries led by India refused to sign off a deal that would adversely affect their agricultural sectors. And as 
the global financial crisis has unfolded it is the G20, not the G8, which has become the key forum for discussion of solutions.

Not coincidentally, as emerging developing countries such as China and India have sought more aggressively to fashion globalization to meet their own ends, so its popularity has waned in western centres of power. As Tabb (2007) has argued, for US elites, globalization means US leadership. But the US is no longer as sure as it was in the mid1990 s that it is in control of the process. Academic and policy opinion in the U.S. has become decidedly more skeptical of the benefits of globalization (Rodrik 2008). Now it is not just labour but capital and the state which have raised concerns about 'unfair competition' from emerging countries - not with respect to labour conditions but also with respect to sovereign wealth funds and resource acquisitions. The new defensiveness of western elites, and of the US in particular together with the global strategies of the Chinese state has led to the current period being described as one of 'protectionist capitalists versus capitalist communists' (Colburn 2005). ${ }^{8}$

There are many debating points here. One of them is whether the Chinese state can really be viewed as unitary state capable of following a developmentalist strategy (Howell 2006), a question which is certainly also applicable to India. But let us assume for the moment that both countries are capable of making use of the development space which they seek. What are implications of this for labour? In a neoclassical world, rising productivity would fuel both growth and rising real wages in both countries. However, history is more complex than this. While East Asian developmental states have seen tremendous increases in real wages this has been in no small degree the result of the often bloody struggles that workers there have waged against brutal regimes for labour and union rights, as Japan circa 1960 and South Korea circa 1980 testify.

On this reading of globalization, the problematic for labour is how to ensure that it receives it share of the benefits from, and has voice in, the economic success of the globalizing developmental state. This requires assessment of internal political structures and dynamics. What are the prospects, for example, for Chinese labour? Is the state monopoly ACFTU capable of playing a more independent role as China economically advances? Or will rents continue to be captured by the new elite of entrepreneurs and cadres with income inequality increasing further? How do the Chinese leaders and cadres, guiding globalization as they see it in the 'national interest', view workers? To many, the answer may seem all too depressingly obvious. But it is of interest to note that as many Western governments continue to dismantle labour protections in the face of globalization, China after years of systematically dismantling the 'iron rice bowl' now appears to be moving in a somewhat different direction with a succession of up-grades to the labour law in recent years. ${ }^{9}$ While this is of interest, further research is needed to determine if this is also of significance.

It is clearly implausible to see, to put it mildly, China - or India - as the agents of globally emancipatory politics. Advocates of counter-hegemonic globalization have good reason for arguing that while 'diminishing disparities among nation states is a valuable agenda ... unless the behaviour of nation states themselves is constrained domestically and 
globally, by a more powerful "movement of movements" they will remain primarily agents of elite interests' (Evans 2008: 285).

We return, then, to the question of whether 'globally constraining' policies, perhaps such as international labour standards, provide a possible mechanism for bringing about the types of societal change which would strengthen labour organizations and movements in developmental states. That is, should there be a quid pro quo for the developmental space that China and India demand in terms of measures that would permit or even encourage the transition to a developmental state in which labour is able to bargain for its share of the productivity gains? The possibility of a specifically 'democratic developmental state' was raised by Gordon White (1998). He argued that such a state would need to have broad control over three functions: regulatory, infrastructure and, importantly for our theme here, redistributive. But for such a state simultaneously to achieve both developmental and democratic objectives would require a specific constellation of institutional design of the state, political society and civil society. It is no surprise that he concluded that 'given the particular characteristics of the democratic developmental state ... it would be reasonable to be skeptical about their feasibility. Democratic developmental states may turn out to be the exception rather than the rule' (1998: 42). Are there external pressures or spaces that might make such exceptions more likely to occur and succeed?

China and India present different challenges in this respect. China as an authoritarian state poses one set of challenges as outlined above. India, as a democratic polity which has shifted to neoliberalism but which nevertheless wishes to claim greater development space, offers a different set. The almost standard account that portrays the organized Indian working class as having been co-opted and rendered politically inconsequential may be overdrawn (Teitelbaum 2006); and in the era of neoliberal economic reforms unions have had some success in resisting measures proposed to enhance the powers of employers (as by the Second National Labour Commission in 2002). It is still the case, however, that in the three-year period of 1994-96, lock-outs [by employers] on average claimed 85 per cent more person days than did strikes. That disproportion further increased in the three years 2002-04 to 218 per cent' (Bidwai 2006). Protective legislation has not hindered employers from making massive reductions in their workforces. The Supreme Court, responding to initiatives of middle class lobby groups, has latterly ruled in support of important welfare measures (including the right to work enacted in the National Rural Employment Guarantee Act), but it has not generally been supportive of labour rights. Poverty is recognized as a major issue, but not redistribution. As Mooij and Dev (2004) noted in an analysis of social policy, 'the human development framework [to which India moved in the later 1990s], sympathetic as it may be, helped to divert attention from the more structural characteristics of poverty', including the availability of employment and the possibilities of 'decent work'. 'Poverty' is a powerful factor politically. Labour is not.

Refashioning the governance of the global economy to allow more development space raises questions, therefore, of how that space can best be used to advance the cause of labour. This relies on analyses of 'internal' political dynamics as well as the possible mechanisms which might be available to influence them from 'outside'. If greater 
development space is either ceded by the core or grabbed by emerging powers then the implications for labour in the core also requires consideration. If economic and political power continues to shift to China and India, analyses of how labour in the core can be accommodated within this beyond the neoclassical emphasis on 'retraining' are required.

One important consideration here is the international policy environment. This reflects the ways in which global shifts are managed. The current environment, with large imbalances as developmental states run large surpluses and the U.S. acts as the consumer of last resort, is fraught with instability as the current global situation, triggered by the credit crisis, demonstrates. New forms of global economic governance which allow developmentalist strategies but which also stress the importance of domestic demand and coordinated international policy responses might be prerequisites for ensuring that the insecurities for labour arising from global power shifts are minimized. That is, in seeking to manage the shifts that are presently underway in the global economy, greater autonomy for the state might also paradoxically require closer international macroeconomic policy coordination for the new configurations to be beneficial to labour.

Even those who are skeptical of the size of the impacts of the global shifts, nevertheless see a new international governance structure as desirable. Singh and Zammit (2004: 99-100), for example, argue that 'the alternative path is essentially one of an international Keynesian regime of managed world trade and controlled international capital movements with measures to increase worldwide demand for labour. The national and international institutions required to provide the basis for such a regime are, not surprisingly, rather different from those underpinning the current globalization project. The alternative model, it is suggested, would not only bring closer North-South cooperation, but also lead to full employment of the world's resources and to a faster rate of economic growth, thereby reducing poverty and helping promote labour standards in both the North and the South.' The space to discuss such alternatives has been opened by the current crisis.

Understanding the dynamics of globalization is therefore a critical task for examining the impacts on labour and formulating effective strategies in response. The three paradigms discussed here propose different theoretical frameworks and analytical tools for addressing the question. These are summarized in Figure 1 below. 
Figure 1: Globalization paradigms, the problematic for labour, and responses

\begin{tabular}{|c|c|c|c|}
\hline Paradigm & $\begin{array}{l}\text { Assumptions/ } \\
\text { Characteristics }\end{array}$ & $\begin{array}{c}\text { Globalization's Problematic for } \\
\text { Labour }\end{array}$ & Policy Issues and Responses \\
\hline $\begin{array}{l}\text { Neoclassical } \\
\text { liberalism }\end{array}$ & $\begin{array}{l}\text { Globalization characterized } \\
\text { as trade and investment } \\
\text { liberalization } \\
\text { Globalization as welfare- } \\
\text { enhancing in the aggregate } \\
\text { Comparative advantage, } \\
\text { based on factor endowments, } \\
\text { explains processes }\end{array}$ & $\begin{array}{l}\text { Job losses and wage reductions in } \\
\text { advanced countries especially in } \\
\text { the import competing sectors } \\
\text { Increasing wage inequality in the } \\
\text { advanced countries } \\
\text { The natural unfolding of the } \\
\text { market pits the interests of workers } \\
\text { in North against those in the South }\end{array}$ & $\begin{array}{l}\text { Local: } \\
\text { Individual human capital upgrading } \\
\text { National: } \\
\text { Job retraining for workers in the core } \\
\text { International: } \\
\text { Protection against imports advocated by } \\
\text { labour in the core } \\
\text { International labour standards as a means } \\
\text { to prevent low labour standards acting as } \\
\text { an 'unfair endowment' for developing } \\
\text { countries }\end{array}$ \\
\hline $\begin{array}{l}\text { Anti-Neoliberal } \\
\text { Globalism }\end{array}$ & $\begin{array}{l}\text { Globalization as a political } \\
\text { project to increase the power } \\
\text { of capital over states and } \\
\text { labour } \\
\text { A response to the profits } \\
\text { crisis of the } 1970 \text { s }\end{array}$ & $\begin{array}{l}\text { Increasing power of capital } \\
\text { (corporations) everywhere } \\
\text { Increased insecurity and } \\
\text { deteriorating working conditions } \\
\text { for workers everywhere as capital } \\
\text { is able to play off jurisdictions and } \\
\text { workers against each other. } \\
\text { Most adversely affected workers } \\
\text { are those in the weakest bargaining } \\
\text { positions e.g. migrant women in } \\
\text { export processing zones }\end{array}$ & $\begin{array}{l}\text { Local: } \\
\text { Collective forms of resistance } \\
\text { National: } \\
\text { Adaptive and competition states too weak } \\
\text { but there is still the possibility of varied } \\
\text { outcomes based on extent of state elite's } \\
\text { embrace of neoliberalism } \\
\text { International: } \\
\text { Corporate codes of conduct/CSR } \\
\text { Global unionism } \\
\text { International minimum wage campaigns } \\
\text { Global social democracy as a way to } \\
\text { regulate global capital or, more radically, a } \\
\text { counter-hegemonic globalization } \\
\text { International labour standards as a way of } \\
\text { reclaiming labour's lost power at the global } \\
\text { level }\end{array}$ \\
\hline $\begin{array}{l}\text { Multi-centred } \\
\text { (developmental) } \\
\text { statism }\end{array}$ & $\begin{array}{l}\text { No single model or source of } \\
\text { globalization } \\
\text { Rise of southern } \\
\text { multinationals } \\
\text { Evolving global governance } \\
\text { structures with developing } \\
\text { states seeking to wrestle } \\
\text { back policy space }\end{array}$ & $\begin{array}{l}\text { Internal dynamics of } \\
\text { developmental states determine } \\
\text { labour organizations' ability to } \\
\text { claim productivity gains } \\
\text { Impact on workers in the advanced } \\
\text { countries of expanding } \\
\text { developmental states in a } \\
\text { deflationary/recessionary world } \\
\text { economy }\end{array}$ & $\begin{array}{l}\text { Local: } \\
\text { Collective forms of resistance and voice } \\
\text { National: } \\
\text { Using national sovereignty to benefit } \\
\text { labour; the possibilities for voice in, or } \\
\text { more strongly a democratic, developmental } \\
\text { state } \\
\text { International: } \\
\text { Importance of global macroeconomic } \\
\text { policy environment } \\
\text { Possibilities for promoting labour rights in } \\
\text { developmental states (a role for } \\
\text { international labour standards?) } \\
\text { Defining policy space; what is 'fair'? }\end{array}$ \\
\hline
\end{tabular}




\section{Conclusions}

Globalization's 'problematic' - its understanding and implications - for labour depends upon the conceptual framework used to understand the term globalization. Much confusion has surrounded the term 'globalization' and its multiple uses have been an obstacle to the analysis of its effects on, and desirable responses by, labour throughout the world. In this paper, I have demonstrated this by analyzing three different paradigms for interpreting globalization. All three posit their own particular problems, identify specific sites where the effects of globalization are expected to be most keenly felt and suggest which strategies at the local, national and international levels are likely to be most appropriate for labour. In so doing, the paradigms assist us in understanding how globalization's impacts in China and India can be best interpreted, what dynamics are at play and what responses can forge solidaristic responses.

In adopting any of three paradigms, it is necessary to ask, as an empirical matter, the extent to which 'globalization', however interpreted, is a key explanatory factor. That is, all paradigms are subject to the globalization skeptic's critique that the forces of globalization have been exaggerated. This is a question relevant to all three paradigms and one which each must seek to assess. The case studies of China and India provided in other papers in this volume provide rich terrain in this regard. They provide us with careful analysis of the ways in which local and national politics acts as critical filters through which globalization must pass and which limit and refract the ways in which globalization is experienced.

If we follow the reasoning of the multi-centred statist argument - or that on deglobalization - as outlined above, then this suggests that the way forward is to develop analysis of the politics of labour within the developmentalist states of China and India, and to enquire as to possible ways in which transnational connections are - or could be involved in these politics. Would such connections be seen as useful by labour organizations in India? Are there even such possibilities for China? Where should the strategic focus of resistance be: at the local, national or global levels? To what extent have international labour standards proven of practical value in expanding democratic space for labour, or what role might they play? Relatedly, what has been the contribution, or what could the contribution be, of consumer-NGO campaigns? What are the connections between workers in different industries in the advanced countries with their counterparts in the re-emergent Asian economies? Are there points of leverage that would create opportunities for global unionism and global bargaining? Or are there positive as well as normative arguments in favour of counter-hegemonic globalization as a promising way forward? Zolberg (1995) has characterized the post-1945 international regime as 'labour friendly'; how can a 'labour friendly' international regime be constructed now as a response to the current global crisis? In clarifying the conceptual terrain of 'globalization' it is hoped this paper can contribute to the answers to these questions. 
ACKNOWLEDGEMENTS

This paper has benefitted from numerous discussions with John Harriss on India and on the concept of 'globalization'.

\section{NOTES}

1 'Globalization skeptics' have critiques of each of these three paradigms. Some of these critiques are noted in the analysis of each paradigm.

${ }^{2}$ For a neoclassical liberal critique of financial liberalization see, for example, Bhagwati (1998).

${ }^{3}$ These impacts arise from the Stolper-Samuelson theorem which states that the return to the scarce factor of production will be reduced with increased specialization and trade. In industrialized countries it is labour that is the (relatively) scarce factor of production. This means that increased trade flows under the auspices of globalization will reduce the return to labour relative to capital in these countries. Conversely, the relative return to labour will be raised in labour abundant (and labour-intensive exporting) developing countries.

4 This argument has been advanced most strongly by the AFL-CIO in the U.S. in its arguments against free trade with China. See, for example, 'When China Represses Workers' Rights, U.S. Workers Lose Jobs', 16 March 2004 (available at http://www.aflcio.org/issues/jobseconomy/globaleconomy/ns03162004.cfm). To this are added charges against China's 'unfair currency manipulation'.

${ }^{5}$ Other studies have suggested that it is not so much trade liberalization as FDI which has increased economic insecurity for workers in the industrialized countries. See Scheve and Slaughter (2004).

6 The three campaigns were those over the Sullivan Code in regard to South Africa; Rugmark in relation to India; and COVERCO regarding the garments industry in Guatemala.

${ }^{7}$ Hay (2006) argues that the European Union is already on the path to 'de-globalization' although it is still one based on the predominance of neoliberalism.

8 This defensiveness was also shown by the Bush administration's willingness to overturn years of diplomacy on nuclear non-proliferation in order to consolidate a strategic alliance with India.

9 The latest of these was introduced in January $1^{\text {st }} 2008$. These changes, the so-called 'five insurances and one allowance', requires all employers to insure employees for medical, retirement and unemployment benefits. The first two are covered by contributions from the employer and employee while the third is paid by the enterprise only. There are also injury and parental leave insurance programs, fully paid by the employer, but both are noncompulsory. In addition, there is an employer and employee joint fund which can be used by employees as a housing contribution (or 'allowance') by the employee when needed. Researchers in China suggest that this change resulted in some labour intensive enterprises 
closing in the Pearl and Yangtze River deltas since they did not want to bear these costs or sign longer term contracts with workers.

\section{REFERENCES}

Befu, H. (2007) “Japanization", "Asianization of the West" and "Creolization": A Perspective from Japan', in P. Bowles and H. Veltmeyer et al (eds), National Perspectives on Globalization (pp. 139-153). Basingstoke: Palgrave Macmillan.

Bello, W. (2002) Deglobalization: Ideas for a New World Economy. London: Zed Books.

Bhagwati, J. (1998) 'The Capital Myth: The Difference Between Trade in Widgets and Dollars', Foreign Affairs 77(3): 7-13.

Bidwai, P. (2005) untitled column in Frontline 22(17): 110.

Cerny, P. (2000) 'Restructuring the Political Arena: Globalization and the Paradoxes of the Competition State', in R. Germain (ed), Globalization and its Critics: Perspectives from Political Economy (pp.117-138). Basingstoke and London: Macmillan Press.

Chan, A. (2001) China's Workers Under Assault: The Exploitation of Labour in a Globalizing Economy. Armonk, NY: M.E. Sharpe.

Colburn, M. (2005) 'Protectionist Capitalists vs. Capitalist Communists', accessed 1 August 2009, http://www.reason.com/news/show/32951.html

Dirlik, A. (2007) 'Global South: Predicament and Promise', The Global South 1(1): 12-23.

Evans, P. (2008) 'Is an Alternative Globalization Possible?', Politics and Society 36(2): 271305

Feenstra, R. (1998) 'Integration of Trade and Disintegration of Production in the Global Economy', Journal of Economic Perspectives 12(4): 31-50.

Gindin, S. (2004) 'Globalization and Labour: Defining the "Problem”, Paper presented at Brandeis University, 24 April 2009.

Goldstein, A. (2007) Multinational Corporations from Emerging Economies: Composition, Conceptualization and Direction in the Global Economy. Basingstoke: Palgrave Macmillan.

Harvey, D. (2005) A Brief History of Neoliberalism. Oxford: Oxford University Press. 
Harvey, D. (2003) The New Imperialism. Oxford: Oxford University Press.

Hay, C. (2006) 'What's Globalization Got to Do with It? Economic Interdependence and the Future of European Welfare States', Government and Opposition 41(1): 1-22.

Howell, J. (2006) 'Reflections on the Chinese State', Development and Change (37)2: 273297.

Jones, R. (2000) Globalization and the Theory of Input Trade. Cambridge: MIT Press.

Kabeer, N. (2004) 'Globalization, Labour Standards, and Women's Rights: Dilemmas of Collective (In)Action in an Interdependent World', Feminist Economics 10(1): 3-35.

Kay, T. (2005) 'Labour Transnationalism and Global Governance', American Journal of Sociology 111(3): 715-56.

Knight, N. (2008) Imagining Globalization in China. Cheltenham: Edward Elgar.

Lal, D. (1999) 'Globalization: What Does it Mean for Developed and Developing Countries?' in H. Siebert (ed), Globalization and Labour (pp. 211-221). Kiel: Institut für Weltwirtschaft an der Universität Kiel.

Leamer, E. (1998) 'In Search of Stolper-Samuelson Linkages between International Trade and Lower Wages' in S. Collins (ed) Imports, Exports and the American Worker (pp. 141202). Washington, DC: Brookings Institution.

Lerner, S. (2007) 'Global Unions: A Solution to Labour's Worldwide Decline', Labour Forum 16(1): 23-37.

Mooij, J. and Dev, M. (2004) 'Social Sector Priorities: An Analysis of Budgets and Expenditures in India in the 1990s', Development Policy Review 22(1): 97-120.

Petras, J. and Veltmeyer, H. (2001) Globalization Unmasked: Imperialism in the Twenty-first Century. London: Zed Books.

Ramos, J. (2004) 'The Beijing Consensus', The Foreign Policy Centre, May.

Rodrik, D. (2008) 'Stolper-Sameulson for the Real World,' accessed 16 June 2009, http://rodrik.typepad.com/dani_rodriks_weblog/2008/06/stolper-samuelson-for-the-realworld.html 
Scheve, K., and Slaughter, M. (2004) 'Economic Insecurity and the Globalization of Production', American Journal of Political Science 48(4): 662-674.

Seidman, G. (2007) Beyond the Boycott. New York: Russell Sage Foundation.

Singh, A. and Zammit, A. (2004) 'Labour Standards and the "Race to the Bottom": Rethinking Globalization and Workers' Rights from Developmental and Solidaristic Perspectives', Oxford Review of Economic Policy 20(1): 85-104.

Sharma, A. (2006) 'Flexibility, Employment and Labour Market Reforms in India', Economic and Political Weekly 41(21): 2078-2086.

Sklair, L. (2001) The Transnational Capitalist Class. Oxford: Blackwell.

Tabb, W. (2007) 'Globalization Means US Leadership: A Perspective from the United States', in P. Bowles, H. Veltmeyer et al (eds), National Perspectives on Globalization (pp. 174-186). Basingstoke: Palgrave Macmillan.

Teitelbaum, E. (2006) 'Was the Indian Labour Movement Ever Co-opted? Evaluating Standard Accounts', Critical Asian Studies 38(4): 389-417.

White, G. (1998) 'Constructing a Democratic Developmental State' in M. Robinson and G. White (eds), The Democratic Developmental State: Politics and Institutional Design (pp. 1750). Oxford: Oxford University Press.

Williamson, P., and Zeng, M. (2007) 'The Global Impact of China's Emerging Multinationals' in C. McNally (ed), China's Emergent Political Economy: Capitalism in the Dragon's Lair (pp. 83-110). London: Routledge.

World Commission on the Social Dimension of Globalization (2004) 'A Fair Globalization: Creating Opportunities For All', http://www.ilo.org/fairglobalization/report/lang-en/index.htm

Yu, K. (2007) 'From Sino-West to Globalization: A Perspective from China' in Paul Bowles, Henry Veltmeyer et al (eds), National Perspectives on Globalization (pp. 44-60). Basingstoke: Palgrave Macmillan,

Zolberg, A. (1995) 'Response: Working-Class Dissolution', International and Working-Class History 47(4): 28-38. 


\section{BIOGRAPHICAL NOTE}

Paul Bowles is Professor of Economics at the University of Northern British Columbia. His research focuses on globalization, regionalism and the political economy of Chinese development. Previous research has included studies of China's financial system, rural industries, and labour systems. He recently published National Currencies and Globalization: Endangered Specie? (Routledge, 2008). He is currently engaged in a project analyzing China's foreign exchange rate regime and currency choices. 